\title{
Examining the Impact of Industry Factors on Organizational Export Performance: The Mediating Role of Promotion Adaptation
}

\author{
Saad Dubayyan Alshammri ${ }^{1}$ \\ ${ }^{1}$ Marketing Management, U.U.M. University, Malaysia \\ Correspondence: Saad Dubayyan Alshammri, Marketing Management, U.U.M university, Malaysia. E-mail: \\ waelbsc@yahoo.com
}

Received: May 27, 2013

Accepted: October 8, 2013 Online Published: November 15, 2013

doi:10.5539/ijbm.v8n23p113

URL: http://dx.doi.org/10.5539/ijbm.v8n23p113

\begin{abstract}
The main purpose of this study is to investigate the impact of Industry Factors on Organizational Export Performance and the Mediating Role of Promotion Adaptation in Malaysian firms involved in manufacturing and exporting products in foreign markets Results indicate that industry Factors has a significant impact on organizational Export Performance under Promotion Adaptation in Malaysian firms involved in manufacturing and exporting products in foreign markets, Technology Intensity has a significant impact on organizational Export Performance under Promotion Adaptation in Malaysian firms involved in manufacturing and exporting products in foreign markets and the Level of Competition has a significant impact on organizational Export Performance through Promotion Adaptation in Malaysian firms involved in manufacturing and exporting products in foreign markets. To achieve Superior performance and hold organizational Excellence, Malaysian firms involved in manufacturing and exporting products in foreign markets must dealing and managing with cases of environmental changing to enhancement export organizational performance for their companies. In addition, Malaysian firms involved in manufacturing and exporting products in foreign markets must provision some flexibility in the completion of the tasks in light controls accuracy and objectivity at the same time to provide different types of means to implementing the tasks.
\end{abstract}

Keywords: industry factors, technology intensity, level of competition, promotion adaptation and organizational export performance

\section{Introduction}

The past few years have witnessed a development in the total number of firms located in emerging economies comprising the global market in Brazil, China, India, and other East Asian countries. The increase can be seen from under 3000 firms to the current total number of firms exceeding 13,000 (UNCTAD, 2006).

This phenomenon stems from a comprehensive internationalization of these countries' firms including advanced economies, emerging and less developed economies. Of the economies comprising the global economy, emerging economies has been acknowledged for the $38 \%$ of world merchandise exports in 2008 (WTO Trade Report, 2009). Emerging countries, comprising of the biggest and fastest growing economies, are molding the stability of the world economy owing to their dynamism and openness. Asian region can be attributed with the major contributions to the world trading with a GDP expansion exceeding 6\% in 2007 as opposed to other regions such as Latin America (3.7\%) and Africa (3\%) (UNCTAD Report, 2008). A majority of these emerging countries are achieving current account surpluses and thus becoming significant capital providers to the rest of the countries in the world (UNCTAD Report, 2008).

The constant participation of the emerging economies from Asia in the form of exports to the global market has enabled the significance of comprehending the firm's international marketing strategy and export performance in this Asian region (Shoham, 1996). Generally, when firms begin penetrating into a foreign market, the main step is to pinpoint the success in the international market is the correct selection of suitable international marketing strategy of either standardization or adaptation (Chung, 2002). Therefore, globalization throughout the international market is significant for international marketers in order to understand the extent of adaptation of their products in international markets.

Countries in South East Asia including Malaysia, Thailand, Vietnam, Indonesia and Philippines are hailed as the 
major players in the global market. The existence of their firms in the foreign markets are becoming very significant as some of them have been listed in the top multinational firms in the world along with multinational firms from developed countries. It is relevant to note that international trading from the Asian region contributes a total of approximately $56 \%$ which represents over half of the world trade flow (UNCTAD, 2009).

Malaysia is considered as one of those countries in Southeast Asia that has recently undergone economic growth and many organizations including the World Bank and the International Monetary Fund considers it as a model of a successful economic development. Recently, Malaysia has been hailed as one of the major trading nations in the world ranking at number seventeen. Malaysian economy has depended on external trade and through a series of a 5-year development plan, the country has transformed itself form a mere exporter of rubber and tin to the world's largest producer of palm oil products, timber, oil and manufactured products. The most impressive significant development is manifested in the manufacturing sector which has replaced agriculture in the spot as the number one economic sector. Today, Malaysia is a world exporter of semi-conductors, air-conditioners and latex-dipped goods. Malaysia, being one of the major trading nations, knows that trade plays a major role in the country's economy and development. To retain its competitiveness and its stable economy, Malaysia realizes that expansion of trade is vital for the country; therefore, Malaysia is constantly seeking for new markets for its products. However, Malaysian firms located in foreign markets are faced by countless obstacles in complicated business surroundings. Environmental factors like legal, political, social-cultural and economic surroundings may represent a similar meaning but their implementation have a very significant affect on a firm's marketing activities. Therefore, according to Jain (1989) and Theodosiou, \& Leonidou (2003), marketing decisions are mostly directed on issues of standardization or adaptation. This leads to the critical issue of the strategic implications linked with the product adaptation and conditions that can affect the export performance in the international marketing strategy especially for a country like Malaysia; a nation that mostly depends on exporting to make significant growths in the economy.

\subsection{Objective of the Study}

Addressing the major issues discussed above, we seek to accomplish the impact of Industry factors (Technology Intensity, Level of Competition) on Organizational Export Performance via Promotion Adaptation.

\subsection{Significance of the Study}

The significance of the current study stems from the Industry factors (Technology Intensity, Level of Competition) and its impact on Organizational Export Performance via Promotion Adaptation. As its significance stems from the limited of studies that addressed the Industry factors and Organizational Export Performance. Also, this study derives its empirical significance from helping decision maker of knowledge of the importance of both Industry factors and Promotion Adaptation in achieving high Organizational Export Performance.

\section{Theoretical Review}

\subsection{Industry Factors}

Standardized marketing strategy is more suitable for technology intensive products such as computer hardware, aircrafts, semiconductors, photographic equipment, heavy equipment, and machine tools than less technology intensive or traditional products such as clothing, food, toiletries, and household cleaners because the latter product category is more sensitive and appeals to tastes, customs, and habits of each society (Cavusgil \& Zou, 1994; Cavusgil, Zou, \& Naidu, 1993; Levitt, 1988). In short, if a product meets universal needs of customers, it requires less adaptation (Jain, 1989). For instance, Corningware's "oven-to-freezer" feature was very popular in the U.S while it did not carve out a big market share in France. Rather, a souffle dish was more popular than "oven to freezer" in France. Corning Glass Works, on the other hand, introduced its electronic and medical products with a standardized marketing strategy because it regarded its product as universal product that did not differ much across international markets (Jain, 1989).

Cavusgil and Zou (1994) observe that firms participating in technology intensive industries should employ a competitive (adapted) pricing strategy to widen their demand base in export markets because it is important to recover the initial large investments in modern technology. Dumagan, et..al, (2003) found that industries that are more IT intensive have experienced higher output growth and productivity growth than less-IT-intensive industries.

\subsection{Promotion Adaptation}

Promotion is one of the marketing mixes, the specification of five promotional mix or promotional plan. These elements are personal selling, advertising, sales promotion, direct marketing, and publicity (Rajagopal, 2007) 
A promotional plan can have a wide range of objectives, including: sales increases, new product acceptance, creation of brand equity, positioning, competitive retaliations, or creation of a corporate image. Fundamentally, however there are three basic objectives of promotion. These are (Kurtz, 2010):

1) To present information to consumers as well as others.

2) To increase demand.

3) To differentiate a product.

Promotional Adaptation may be of the push or pull variety. A company with a Push strategy will aggressively push its product through wholesalers \& retailers, who persuade customers to buy it (Jaradat, et..al, 2011). Marketing factors include product, promotion, channels and price (Wu,Tian \&Yao,2006).

\subsection{Organizational Export Performance}

Studies have been anchored more formally in the RBV paradigm (Lages, 2009). In the export performance literature. Export performance is whether success of failure of the efforts made by an enterprise or a country in bringing its goods and/or services to penetrate the market of other countries. Export performance may be measured through such indicators as sales figures, profits, marketing scales or other subjective measuring tools, customer satisfaction as an example (Nguyen, 2012). Lages, et..al, (2005) stated export performance can be described in objective terms such as sales, profits, or marketing measures or by subjective measures such as distributor or customer satisfaction.

\section{Conceptual Framework and Hypotheses Development}

\subsection{Conceptual Framework}

The proposed conceptual model guiding this research is depicted in Figure (1). As can be seen in the figure, we hypothesize Industry Factors as a multi-dimensional construct consisting of two dimensions: Technology Intensity and Level of Competition. These two dimensions were modeled with Promotion Adaptation as a mediate variable and Organizational Export Performance as the dependents.

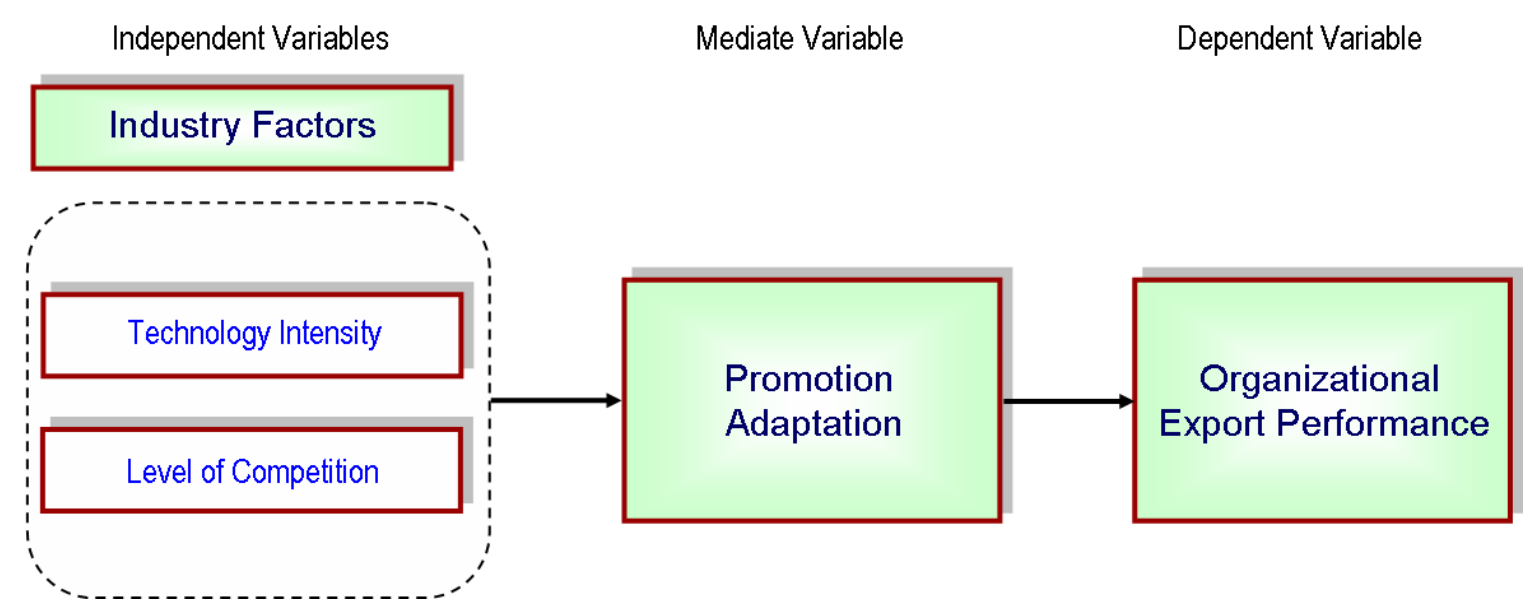

Figure 1. The conceptual model

We suggest Industry Factors to be significant determinant of Organizational Export Performance via Promotion Adaptation i.e. more Industry Factors lead to identify Organizational Export Performance via Promotion Adaptation. Then, we propose that Promotion Adaptation act as antecedents to Organizational Export Performance.

\subsection{Research Hypotheses}

Therefore, to examine these relationships we developed three research hypotheses:

$\mathrm{H}_{1}$ : Industry Factors (Technology Intensity and Level of Competition) has positive direct impact on Organizational Export Performance via Promotion Adaptation.

\section{Research Methodology}

This study is descriptive quantitative in nature, aiming to develop a better understanding of the Industry Factors 
and its relation to Organizational Export Performance via Promotion Adaptation.

\subsection{Selection of Population and Sample}

The population chosen for the current study is the Malaysian firms involved in manufacturing and exporting products in foreign markets. The population frame is taken from an authoritative source published by the Ministry of International Trade and Industry (MITI) and Federation of Malaysian Manufacturers (FMM). This frame will assist the study in accessing the database namely Malaysian Industry and Development Authority (MIDA) database published by MITI along with another necessary database known as FMM Directories published by FMM.

In both databases are listed more an excess of more than 2000 firms; not all of these firms are involved in exporting. Therefore, a sample of firms who are indeed involved needs to be identified, detected and listed. The number of firms included in the culled sample will represent the real population and sample whereby census sampling is used for the purpose of enhancement and increment of the response level.

\subsection{Data Analysis}

The data collected from the responses was treated through SPSS "Statistical Package for Social Sciences". Descriptive and inferential statistics are used to analyze the data for the purpose of examining the degree of adaptation and their effect on firm's export performance. Descriptive statistics comprises of reliability test, frequencies, descriptive and correlation, while inferential statistics comprises of ANOVA and regression analysis.

\subsection{Scale and Measurement}

To achieve study objectives required developing a scale for the study variables "Industry Factors, Promotion Adaptation and organizational Export performance". After conducting a survey on the available measurements for measuring Industry Factors we have depend on the five Likert scale (" 1 " Do not agree to " 5 " Agree completely). For Promotion Adaptation variable. The researcher uses scale a five Likert-scale ("1" Do not agree to "5" Agree completely). In measuring organizational Export performance variable. The researcher adapting scale on Likert measurement from ("1" very low to " 5 " very high).

\subsection{Measure Reliability}

The reliability analysis applied to the level of Cronbach Alpha $(\alpha)$ is the criteria for internal consistency, which was at a minimum acceptable level (Alpha $\geq 0.60$ ). Table 1 illustrative the consistency for study variables.

Table 1. Reliability analysis of industry factors, promotion adaptation and organizational export performance

\begin{tabular}{lcc}
\hline \multicolumn{1}{c}{ Variables } & Dimensions & Cronbach alpha \\
\hline \multirow{2}{*}{ Industry Factors } & Technology Intensity & 0.946 \\
& Level of Competition & 0.957 \\
Promotion Adaptation & & 0.947 \\
Organizational Export Performance & 0.979 \\
Overall Questionnaire & & 0.982 \\
\hline
\end{tabular}

As shown in table (1) Cronbach alpha reliability are acceptable levels. The overall Cronbach alpha of questionnaire is (0.982). Sekaran (2003) indicated (0.60) to be an acceptable reliability coefficient.

\section{Results}

Through using path analysis, significant effects were found between Industry Factors, Promotion Adaptation and Organizational Export Performance

\subsection{Test of Hypotheses}

$\mathrm{H}_{1}$ : Industry Factors (Technology Intensity and Level of Competition) has positive direct impact on Organizational Export Performance via Promotion Adaptation.

To examine this hypothesis, path analysis was uses by considering Organizational Export Performance as the respondent variable, the two dimensions of Industry Factors: Technology Intensity and Level of Competition as independent variables and the Promotion Adaptation as a mediate variable. Table (2) illustrates the path analysis 
results analysis.

Table 2. Path analysis of the impact of industry factors on organizational export performance through promotion adaptation

\begin{tabular}{lccc}
\hline \multicolumn{1}{c}{ Path } & T Statistics & Sig & Result \\
\hline IF $->$ PA & 11.971 & 0.000 & Significant \\
PA $->$ OEP & 6.558 & 0.000 & Significant \\
\hline
\end{tabular}

Table 2 illustrates that industry Factors has a significant impact on organizational Export Performance. The path model showed a high level of fit, as reflected by "T" value (11.971) for the impact of industry Factors on Promotion Adaptation and (6.558) for the impact of Promotion Adaptation on organizational Export Performance. This mean there is a positive impact of industry Factors on organizational Export Performance through Promotion Adaptation, which mean the increased attention to industry Factors under Promotion Adaptation would generate an impact on the organizational Export Performance of Malaysian firms involved in manufacturing and exporting products in foreign markets.

\subsubsection{Hypothesis One}

$\mathrm{H}_{1-1}$ : Technology Intensity has positive direct impact on Organizational Export Performance via Promotion Adaptation.

To examine this hypothesis, path analysis was uses by considering Organizational Export Performance as the respondent variable, Technology Intensity as independent variables and the Promotion Adaptation as a mediate variable. Table (3) illustrates the path analysis results analysis.

Table 3. Path analysis of the impact of technology intensity on organizational export performance through promotion adaptation

\begin{tabular}{cccc}
\hline Path & T Statistics & Sig & Result \\
\hline TI -> PA & 6.635 & 0.000 & Significant \\
PA -> OEP & 6.558 & 0.000 & Significant \\
\hline
\end{tabular}

Table 3 illustrates that Technology Intensity has a significant impact on organizational Export Performance. The path model showed a high level of fit, as reflected by "T" value (6.635) for the impact of Technology Intensity on Promotion Adaptation and (6.558) for the impact of Promotion Adaptation on organizational Export Performance. This mean there is a positive impact of Technology Intensity on organizational Export Performance through Promotion Adaptation, which means the increased attention to Technology Intensity under Promotion Adaptation would generate an impact on the organizational Export Performance of Malaysian firms involved in manufacturing and exporting products in foreign markets.

\subsubsection{Hypothesis Three}

$\mathrm{H}_{1-2}$ : Level of Competition has positive direct impact on Organizational Export Performance via Promotion Adaptation.

To examine this hypothesis, path analysis was uses by considering Organizational Export Performance as the respondent variable, Level of Competition as independent variables and the Promotion Adaptation as a mediate variable. Table (4) illustrates the path analysis results analysis.

Table 4. Path analysis of the impact of level of competition on organizational export performance through promotion adaptation

\begin{tabular}{lccc}
\hline \multicolumn{1}{r}{ Path } & T Statistics & Sig & Result \\
\hline LC -> PA & 9.234 & 0.000 & Significant \\
PA -> OEP & 6.558 & 0.000 & Significant \\
\hline
\end{tabular}


Table 3 illustrates that Level of Competition has a significant impact on organizational Export Performance. The path model showed a high level of fit, as reflected by "T" value (6.635) for the impact of Level of Competition on Promotion Adaptation and (6.558) for the impact of Promotion Adaptation on organizational Export Performance. This mean there is a positive impact of Level of Competition on organizational Export Performance through Promotion Adaptation, which means the increased attention to Level of Competition under Promotion Adaptation would generate an impact on the organizational Export Performance of Malaysian firms involved in manufacturing and exporting products in foreign markets.

\section{Conclusions and Implications}

This current study provides an applied examining of the impact Industry Factors on Organizational Export Performance and the mediating Role of Promotion Adaptation. The empirical study shows that industry Factors has a significant impact on organizational Export Performance under Promotion Adaptation in Malaysian firms involved in manufacturing and exporting products in foreign markets. These results meet with Cavusgil \& Zou (1994) findings competitiveness, \& brand familiarity of export customers have a significant effect on product and promotion adaptation, support to foreign distributor/subsidiary \& price competitiveness. Product and promotion adaptation, support to foreign distributor/subsidiary \& price competitiveness

The path analyses results support the current study hypothesis. Consistent with H1-1, that Technology Intensity has a significant impact on organizational Export Performance under Promotion Adaptation in Malaysian firms involved in manufacturing and exporting products in foreign markets. This result is difference with Cavusgil \& Zou (1994) findings competitiveness, \& brand familiarity of export customers have a significant effect on product and promotion adaptation, support to foreign distributor/subsidiary \& price competitiveness. Product and promotion adaptation, support to foreign distributor/subsidiary \& price competitiveness. Respecting with H1-2, the Level of Competition has a significant impact on organizational Export Performance through Promotion Adaptation in Malaysian firms involved in manufacturing and exporting products in foreign markets. This result indicates that there is no significant effect of competition level on performance of Malaysian export companies. This result is difference with Cavusgil \& Zou (1994) findings export market competitiveness have a significant effect on product and promotion adaptation, Cavusgil et al. (1993) findings export market competitiveness, have a significant effect on product and/or promotion adaptation and Chung (2003) findings competitive environment had a significant effect on the marketing mix standardization.

The current study gives an applied guide of the Impact of Industry Factors on Organizational Export Performance and the Mediating Role of Promotion Adaptation. Based on the above, Malaysian firms involved in manufacturing and exporting products in foreign markets can benefits from current results to reformulation comprehensiveness Strategy that will help to achieving excellence and enhancing export organizational performance. To achieve Superior performance and hold organizational Excellence, Malaysian firms involved in manufacturing and exporting products in foreign markets must dealing and managing with cases of environmental changing to enhancement export organizational performance for their companies. In addition, Malaysian firms involved in manufacturing and exporting products in foreign markets must provision some flexibility in the completion of the tasks in light controls accuracy and objectivity at the same time to provide different types of means to implementing the tasks. Finally, Malaysian firms involved in manufacturing and exporting products in foreign markets must conduct continuous surveys to get feedback from customers and their preferences about the product and services offered, levels and prices and their suitability to the customers needs and wishes, especially the expected (future).

\section{References}

Cavusgil, S. T., \& Zou, S. (1994). Marketing Strategy Performance Relationship: An Investigation of the Empirical Link in Export Market Ventures. Journal of Marketing, 58(1), 1-21. http://dx.doi.org/10.2307/1252247

Cavusgil, S. T., Zou, S., \& Naidu, G. M. (1993). Product and Promotion Adaptation in Export Venture: An Empirical Investigation. Journal of International Business Studies, 24(3), 479-505. http://dx.doi.org/10.1057/palgrave.jibs.8490242

Chung, H. F. L. (2002). An Empirical Investigation of Marketing Prgramme and process Elements in the Host-Home Scenario. Journal of Global Marketing, 16(1), 141-186.

Dumagan, J., Gill, G., \& Ingram, C. (2003). Industry level effects of IT use on productivity and inflation. In D. Evans (Ed.), Digital Economy 2003 (pp. 41-60). Washington, DC: U.S. Department of Commerce.

Jain, S. C. (1989). Standardization of International Marketing Strategy: Some Research Hypothesis. Journal of 
Marketing, 53(1), 70-79. http://dx.doi.org/10.2307/1251525

Jaradat, A. A. S., Jaradat, M., \& Yassine, F. L. A. (2011). Promotion objectives, strategies and tools. Interdisciplinary Journal of Contemporary Research in Business, 3(2), 1682-1693.

Kurtz, D. (2010). Contemporary Marketing Mason. OH: South-Western Cengage Learning.

Lages, L. F., Silva, L., \& Styles, C. (2009). Relationship Capabilities, Quality, and Innovation as Determinants of Export Performance. Journal of International Marketing, 17(4), 47-70. http://dx.doi.org/10.1509/jimk.17.4.47

Lages, L. F., Carmen, L., \& Cristiana, R. L. (2005). Bringing export performance metrics into annual reports: The APEV scale and the PERFEX scorecard. Journal of International Marketing, 13(3), 79-104. http://dx.doi.org/10.1509/jimk.13.3.79

Levitt, T. (1998). The Globalization of Markets. Harvard Business Review, 61(3), 92-102.

Nguyen, H. (2012). International Marketing Capacities and Export Performance: An Empirical Study of Indochinese Exporting Enterprises. International Journal of Marketing Studies, 4(4), 51-59. http://dx.doi.org/10.5539/ijms.v4n4p51

Rajagopal. (2007). Marketing Dynamics: Theory and Practice. New Delhi, India: New Age International. Retrieved April 5, 2010, from http://www.njit.eblib.com.libdb.njit.edu:8888/patron/FullRecord.aspx?p=437711

Sekaran, U. (2003). Research Methods for Business. John Wiley \& Sons.

Shoham, A. (1996). Marketing Mix Standardization: Determinants of Export Performance. Journal of Global Marketing, 10(2), 53-73. http://dx.doi.org/10.1300/J042v10n02_04

Theodosiou, M., \& Leonidou, L. C. (2003). Standardization versus Adaptation of International Marketing Strategy: An Integrative Assessment of the Empirical Research. International Business Review, 12(2), 141-71. http://dx.doi.org/10.1016/S0969-5931(02)00094-X

World Trade Organization. (2009). World Trade Report 2009. Retrieved from http://www.wto.org/english/res_e/booksp_e/anrep_e/world_trade_report09_e.pdf

\section{Copyrights}

Copyright for this article is retained by the author(s), with first publication rights granted to the journal.

This is an open-access article distributed under the terms and conditions of the Creative Commons Attribution license (http://creativecommons.org/licenses/by/3.0/). 